\title{
ANTIMICROBIAL ACTIVITY OF LEAF EXTRACTS OF NARINGI CRENULATA.
}

\author{
M. Rambabu ${ }^{1}$, Dr.S.K.M.Basha ${ }^{2}$ and Dr.C.V.Narasimha murth ${ }^{3}$
}

\begin{abstract}
Traditional medicines have become more popular in the treatment of many diseases due to popular belief that green medicine is safe, easily available and with fewer side effects. The World Health Organization (WHO) estimated that $80 \%$ of the population of developing countries relies on traditional medicines, mostly plant drugs, for their primary health care needs. The scientific evaluation of ethno medicinally important plants is now being done thoroughly covering various aspects of their study like efficacy of the crude drugs, chemistry of active principles, and its therapeutic effects. Naringi crenulataRoxb (or) Limonia crenulata is a Rutaceae family, spinous glabrous small

tree, grows tropical Africa and Asia. It is commonly known as "Mahavilvam" inTamil and Kukka velaga in Telugu. It is a wide spread of the genus (Naringi) grown as under large trees in evergreen forests upto $200 \mathrm{mts}$. The leaves are aromatic just like any other citrus leaves. The root extract is used for vomiting, dysentery and colic disorders. Fruit decoction is used as an antidote to insect poison. In the present study an attempt is made various photochemical those are there in the leaf of Naringi crenulataRoxb and its antimicrobial activity. The results shows compounds such as alkaloids flavonoids, tannins, saponins, steroids and terpenoids are detected in $N$. crenulata which could made the plant useful for treating different ailments as having a potential of providing useful drugs of human use.

Keywords- Naringi crenulata, Leaf, phytochemical studies, antibacterial activity.
\end{abstract}

\section{INTRODUCTION}

Naringi crenulata (Roxb.) Nicolson is a tropical medicinal palnt belonging to Rutaceae family. It is popularly called as Ekadasa Bilvarm or Kukka velaga in Telugu language. From immemorial period it is used for treating various ailments such as vomiting, dysentery and digestive disorders. The bark is used for muscle sprains. Earlier studies shows that the bark of this plant is having as anticancer, [1] hepatoprotectivity [2] aphrodisiac activity [3], anti-inflammatory activities [4]. However in the present study an attempt is made to know the preliminary phytochemical composition of Leaf and its antibacterial properties.

\section{MATERILS AND METHODS}

\section{Naringi crenulata}

Trees, grows up to $10 \mathrm{~m}$, armed with sharp solitary or paired axillary spines; bark yellowish-grey, smooth, corky; blaze yellow; branch lets angled, glabrous. Leaves imparipinnate, alternate, estipulate; rachis $2.5-10 \mathrm{~cm}$ long, winged, wings obovate-oblong, glabrous, punctate; leaflets 3-7, opposite, sessile, estipellate; lamina 1-6 x 0.7-2.4 cm, elliptic or elliptic-obovate, base acute or obliquely acute, apex obtuse to emarginate, margin crenate, glabrous, profusely pellucid-gland dotted; glands dimorphic; coriaceous; lateral nerves 4-10 pairs, pinnate, slender, faint, intercostae reticulate, faint. Flowers bisexual, white, in few flowered axillary racemes; pedicel 8-10 mm long; sepals 4, free or united at base, ovate-orbicular, glandular; petals 4, free, elliptic or oblong, white, glandular, glabrous;

\footnotetext{
${ }^{1}$ Department of Botany Rayalaseema University, Kurnool, A.P., India

${ }^{2}$ Associate professor V.S.University P.G.Center, Kavali. SPSR Nellore Dt.A.P.

${ }^{3}$ Associate professor V.S.University P.G.Center, Kavali. SPSR Nellore Dt.A.P.
} 
stamens 8, subequal, free, inserted round the disc; filaments subulate; anthers yellow, apiculate, disc thin, glandular; ovary superior, globose, 4-celled, glabrous, glandular, ovule 1 in each cell.; style stout; stigma capitate; Fruit a berry, 6-8 mm across, subglobose, bluish-black, glandular; seeds 1-4, dull yellow, smooth.

\section{Material}

Fresh leaves were collected from Siddeswarm Sacred grove of Seetharamapuram mandal of SPSR Nellore District. During the field visit leaves are collected air-dried and pulverized and sieved through 40 mesh. Preliminary phytochemical tests of Aqeousj, Methanolic, Methanolic and Petroleum ether extracts were preformed using specific reagent(5) The powdered leaves were extracted with Methanol in a soxhlet apparatus. The extract was dried in a heated vacuum dissector and dried extract thus obtained was analyzed for phytochemical and antimicrobial tests. The antibacterial activities of this extract were tested against Bacillus subtilis, Escherisia coli, Salmonella typhi and Staphylococcus aureus. The antifungal activities of the extracts were tested against Aspergillus and Aspergillus niger. The antibacterial and antifungal activity was checked by paper disc diffusion method. A standard disc containing Ciprofloxacin antibiotics was used as control standard.

\section{Phytochemical screening procedure}

\section{Test for alkaloids}

Test substance shaken with few drops of $2 \mathrm{~N}$ HCL. Aqueous layer formed, decanted and to which one or two drops of Mayer's reagent added. Formation of white turbidity or precipitate indicated the presence of alkaloids.

\section{Test for flavonoids}

Shinado's test: To the substance in alcohol, a few magnesium turnings and few drops of concentrated hydrochloric acid were added and boiled for five minutes. Red coloration showed the presence of flavonoids.

\section{Test for Phenols}

Elagic acid test: The test solution was treated with few drops of $5 \%(\mathrm{~W} / \mathrm{V})$ glacial acetic acid and $5 \%(\mathrm{~W} / \mathrm{V}) \mathrm{NaNO}_{2}$ Solution. Muddy or Niger brown colored precipitate indicates the presence of phenols.

\section{Test for tannins}

The substance mixed with basic lead acetate solution. Formation of white precipitate indicated the presence of tannins.

\section{Test for saponins}

The substance shaken with water, foamy lather formation indicated the presence of saponins.

\section{Test for triterpenoids}

Noller's test: The substance was warmed with Tin and Thionyl chloride. Purple coloration indicated the presence of triterpeniods.

\section{Test for steroids}

One gram of the test substance was dissolved in a few drops of acetic acid, acetic anhydride, warmed and cooled under tap water and a drop of concentrated sulphuric acid was added along the sides of the test tube. Presence of green colour indicated the presence of steroids.

\section{Test for coumarin}

To the test sample $10 \%$ of sodium hydroxide and chloroform were added. Formation of yellow colour indicated the presence of coumarin.

\section{Test for quinones}

To the test substance, sodium hydroxide was added. Blue green or red colour indicated the presence of quinones.

\section{Antimicrobial studies:}

\section{Preparation of Nutrient Agar media:}

For the preparation of 1 liter of Nutrient Agar media ingredients like $1.5 \mathrm{~g}$ of beef extract, $1.5 \mathrm{~g}$ of yeast extract, $5 \mathrm{~g}$ of peptic digest of animal tissue and $5 \mathrm{~g}$ of sodium chloride were weighed and added in 500 
$\mathrm{ml}$ of distilled water and heated with stirring to dissolve the constituents. Finally, the values were made up to liter. Before the addition of agar $(15 \mathrm{~g})$ the $\mathrm{pH}$ of the medium is adjusted to 7.0 by adding few drops of $0.1 \mathrm{~N} \mathrm{NaoH}$ or $\mathrm{HCl}$ using digital $\mathrm{pH}$ meter(Elico Pvt Ltd, Hyderabad). Then the media sterilized by autoclaving at $15 \mathrm{lbs}$ pressure at $120^{\circ} \mathrm{C}$ for $15 \mathrm{~min}$, and then cooled to $40^{\circ} \mathrm{C}$ and approximately $20 \mathrm{ml}$ of medium was poured to each $90 \mathrm{~mm}$ sterilized petridish.

Preparation of inoculums: $18 \mathrm{hrs}$ old bacterial broth cultures was used as inoculums after adjusting its population to $10^{6} \mathrm{CFU} / \mathrm{ml}$ (Colony Forming Units) using $0.9 \%$ ( W/V) sterile saline.

\section{Antibacterial Assays by Disc diffusion method:}

The antibacterial activity of isolated aqueous and Methanolic plant extract was tested by standard disc diffusion method. The tested bacteria were maintained on nutrient agar (Hi media) slants.

A loof ful of culture from the slant was inoculated into the nutrient agar broth and inoculated at $37^{\circ} \mathrm{C}$ for $24 \mathrm{hrs}$ and $0.1 \mathrm{ml}$ of this culture was evenly spread on the nutrient agar plate. Sterile discs of Whitman No.1 filter paper of about $6 \mathrm{~mm}$ diameter were placed on the surface of the media using sterile micropipette, $20 \mu \mathrm{l}(0.02 \mathrm{mg})$ of the sample of plant extracts was applied on the discs and incubated at $35^{\circ} \mathrm{C}$ for $24 \mathrm{hrs}$. Streptomycin $(10 \mu \mathrm{g} / \mathrm{ml})$ used as standard drug for bacterial strains and Fluconazole $(10 \mu \mathrm{g} / \mathrm{ml})$ used as standard drug for fungal organisms. After incubation, the plates were observed for zones of inhibition surrounding the disc. Zones of inhibition were measured by using the scale and the results obtained were tabulated.

\section{RESULTS}

Presence or absence of certain important compounds in an extract is determined by color reactions of the compounds with specific chemicals which act as dyes. The knowledge of the chemical constituents is desirable to understand the herbal drug preparations(6). The present study only reveals the presence of diverse phyto-constituents. Further thorough study is required to develop the novel bio active components of therapeutic potential.

Bioactive compounds such as alkaloids flavonoids, tannins, saponins, steroids and terpenoids are detected in $N$. crenulata Leaf, which could made the plant useful for treating different ailments as having a potential of providing useful drugs of human use.

Table: preliminary Phytochemical screening of leaf extracts of Naringi crenulata

\begin{tabular}{|l|l|c|c|c|c|}
\hline S.No & Constituents & Aqueous & Methanol & Ethanol & Petroleum ether \\
\hline 1. & Alkaloids & ++ & ++ & ++ & - \\
\hline 2. & & & & & \\
\hline 3. & Flavonoids & + & + & + & - \\
\hline 4. & Thenols & ++ & ++ & ++ & + \\
\hline 5. & Sannins & ++ & ++ & + & - \\
\hline 6. & Terpenoids & + & + & + & + \\
\hline 7. & Steroid & - & - & - & - \\
\hline 8. & Coumarin & + & + & + & - \\
\hline 9. & Glycosides & - & + & + & + \\
\hline 10. & Quinones & - & - & + & - \\
\hline
\end{tabular}

Photographs showing the effect of agues extract of leaf on different microbial cultures. 

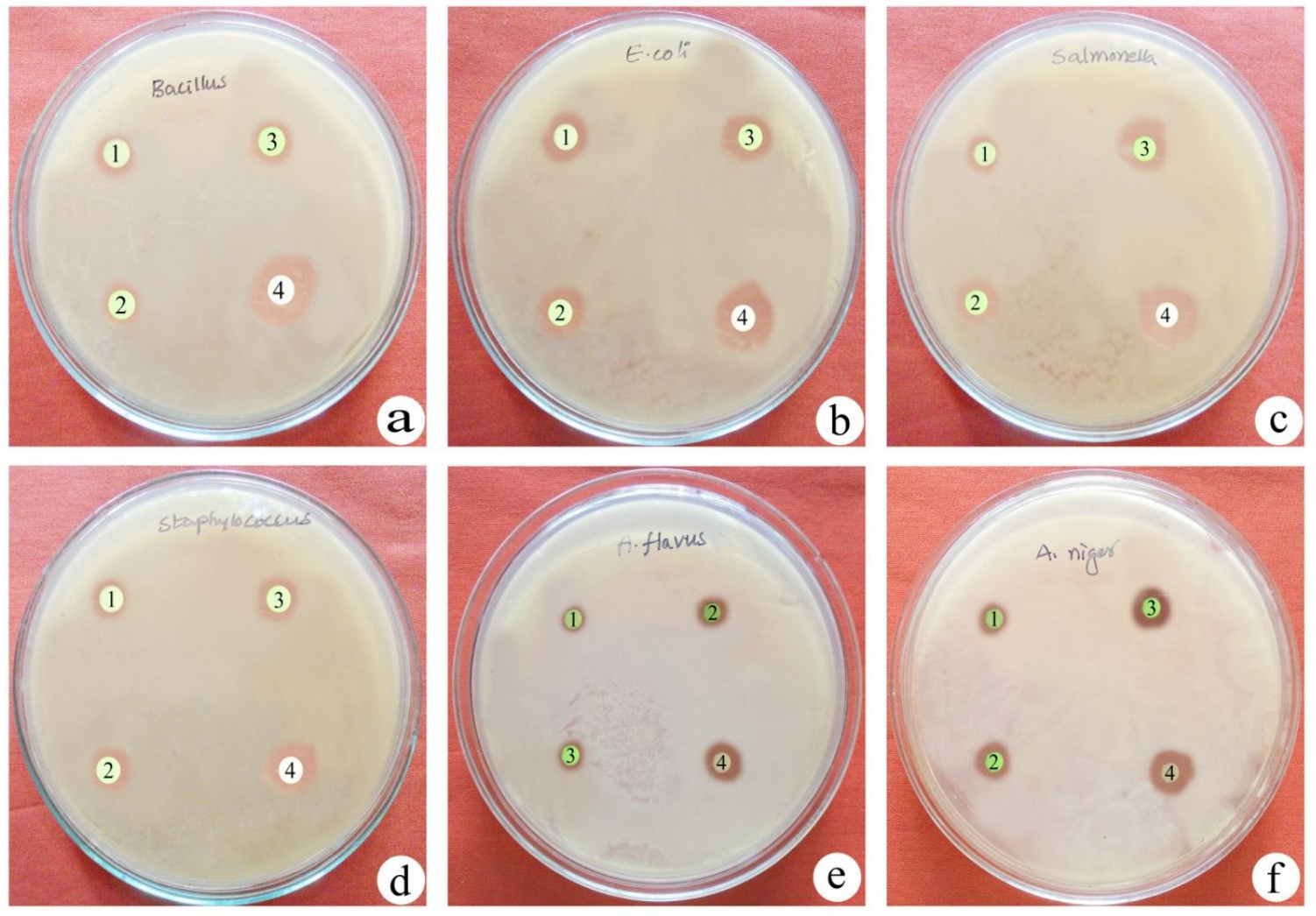

Table-2.

Effect of leaf extract on the antibacterial activity on various microbes

\begin{tabular}{|l|l|l|l|l|l|}
\hline \multirow{2}{*}{ S. No } & \multirow{2}{*}{$\begin{array}{l}\text { Name of } \\
\text { Microorganism }\end{array}$} & \multicolumn{4}{|l|}{ Concentration $(\mu \mathrm{g} / \mathrm{ml})$} \\
\cline { 3 - 6 } & & 25 & 50 & 75 & $\begin{array}{l}\text { Streptomycin } \\
\text { Fluconazole }(10 \mu \mathrm{g} / \mathrm{ml})\end{array}$ \\
\hline 1. & Bacillus subtilis & $7.6 \pm 0.05$ & $7.8 \pm 0.09$ & $8.1 \pm 0.02$ & $10.2 \pm 0.04$ \\
\hline 2. & Escherichia coli & $7.9 \pm 0.04$ & $8.2 \pm 0.08$ & $8.5 \pm 0.07$ & $10.5 \pm 0.02$ \\
\hline 3. & Salmonella typhimurium & $7.2 \pm 0.03$ & $7.7 \pm 0.04$ & $8.6 \pm 0.05$ & $10.6 \pm 0.02$ \\
\hline 4. & Staphylococcus aureus & $7.2 \pm 0.05$ & $7.4 \pm 0.04$ & $7.9 \pm 0.08$ & $8.6 \pm 0.03$ \\
\hline 5. & Aspergillus flavus & $7.1 \pm 0.04$ & $7.2 \pm 0.05$ & $7.5 \pm 0.05$ & $8.1 \pm 0.03$ \\
\hline 6. & Aspergillus niger & $7.2 \pm 0.02$ & $7.4 \pm 0.04$ & $7.8 \pm 0.05$ & $8.4 \pm 0.08$ \\
\hline
\end{tabular}

Graph showing the effect of different concentrations of leaf extract on different microbes. 


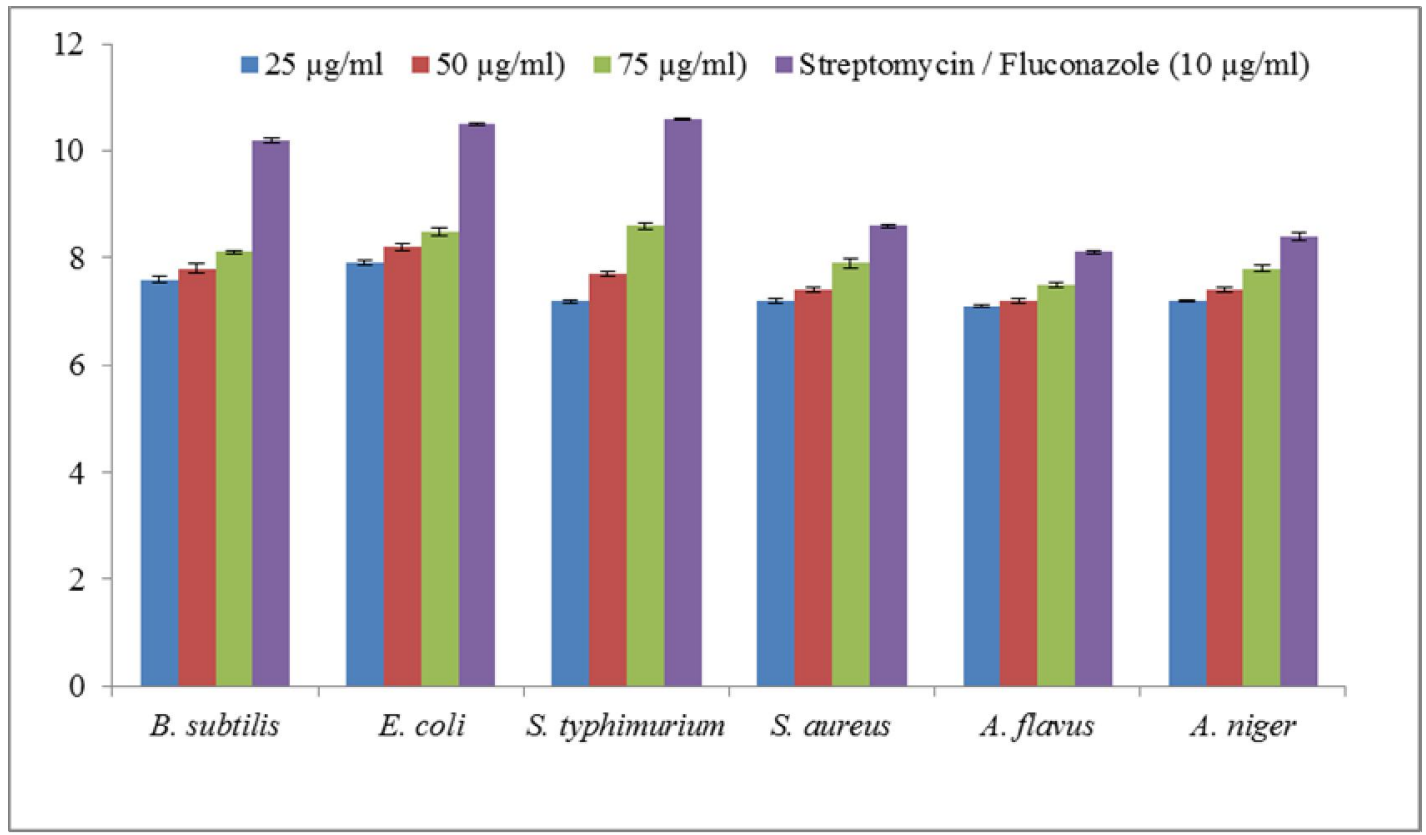

\section{CONCLUSION}

The Naringi crenulata appear to be rich in secondary metabolites, widely used in traditional medicine to combat and cure various ailments. The anti-inflammatory, antispasmodic, analgesic and diuretic can be attributed to their high phenols, tannins, triterpenoids, saponins and flavonoids. Exploitation of these pharmacological properties involves further investigation of these active ingredients by implementation of techniques like extraction, purification, separation, crystallization and identification.

\section{REFERENCES}

[1]. Sarada K, Jothibai Margret R and Mohan V.R. Anticancer activity of ethanol extract of leaf and bark of Naringi crenulata against Ehrlich Ascites carcinoma. Int. J. Res. Pharm. Chem. 2012. 2: 267-272

[2]. Sarada K, Jothibai Margret R, Mohan V.R. Hepatoprotective and antioxidant activity of ethanol extracts of Narirgi crenulata (Roxb) Nicolson against CCl4 included hepatotoxicity in rats. Int. J. Pharmaceu. Sci. Res. 2012; 3: 874880.

[3]. Sarada K, Jothibai Margret R, Mohan V.R. Aphrodisiac potential of ethanol extracts of leaf and bark of Naringi crenulata (Roxb.) Nicolson in male rats. In: Proceedings of the International conference on "Biologically active molecules" organized by Department of Chemistry, Gandhi gram Rural Institute-Deemed University, Gandhigram. March, 2012.

[4]. Sarada K., Jothibai Margret R, Mohan V. R. Antiinflammatory activity of ethanol extracts of leaf and bark of Naringi crenulata (Roxb.) Nicolson. Int. J. Pharmaceu. Sci. Res. 2012; 3: 4540-4544.

[5]. Trease,G.E.\&Evans, W.C. 1985. Pharmacognosy 9th Edn., ELBS publication.

[6]. Savithramma N, Linga Rao M, Ankanna S. Preliminary Phytochemical Analysis of Traditionally used Medicinal Plants Int J Res .Pharm Sci 2012; 3(1):311-314. 